\title{
МІЖНАРОДНЕ ПРАВО
}

УДК 341.1

DOI https://doi.org/10.32844/2618-1258.2019.3-2.39

ДУБОВИк в.Б.

\section{УКРАЇНА - ОБСЄ: АКТИВІЗАЦІЯ СПІВРОБІТНИЦТВА У ФОРМУВАННІ СУЧАСНОЇ СИСТЕМИ БЕЗПЕКИ}

У статті проаналізовано етапи співробітництва України з ОБСЄ за різними напрямами в умовах формування сучасної світової системи безпеки. Охарактеризовано різноманітність форм і проектів співпраці із ОБСЄ, що мають на меті врегулювання міжнародних та локальних конфліктів, стабілізації без пекової ситуації в Європі, миротворчі місії та операції. Виокремлено особливості діяльності спеціальної моніторингової місії ОБСЄ в Україні.

Наголошено, що польові операції створюються на запрошення відповідних приймаючих країн, а їх мандати затверджуються державами-учасниками на основі консенсусу. Вони надають підтримку країнам у підвищенні потенціалу шляхом реалізації проектів, що відповідають потребам і потребам приймаючої країни.

Зроблено висновок, що ОБСЄ служить форумом для політичного діалогу 3 широкого кола питань безпеки і платформою для спільної діяльності щодо поліпшення життя людей і співтовариств. ОБСЄ сприяє подоланню розбіжностей формуванню довіри і співпраці, як між державами, так і всередині них. Там, де $\epsilon$ нестабільність, ОБСЄ працює над запобіганням конфліктів, регулюванням криз і постконфліктним відновленням За допомогою своїх інститутів, експертних підрозділів і мережі польових операцій ОБСЄ займається низкою запитань, що впливають на нашу загальну безпеку, включаючи контроль над озброєннями, тероризм, належне врядування, енергобезпека, торгівлю людьми, демократизацію, свободу засобів масової інформації та національні меншини.

Спільно з ОБСє Україна реагує на виклики сучасності та формує безпековий вимір загальноєвропейської політики. Крім того, активізація співробітництва України з ОБСЄ розглядається як один із найважливіших компонентів процесу європейської та євроатлантичної інтеграції нашої держави, реалізації національних інтересів нашої країни, забезпечення її територіальної цілісності та недоторканості кордонів, стабільності, міжнародного визнання, розвитку як демократичної правової держави.

Ключові слова: ОБСЄ, спеціальна моніторингова місія ОБСЄ, безпека, Україна, міжнародний конфлікт, не міжнародний конфлікт, миротворча діяльність.

The article analyzes the stages of Ukraine's cooperation with the OSCE in various directions in the context of the formation of a modern world security system. A variety of forms and projects of cooperation with the OSCE aimed at resolving international and local conflicts, stabilization without a pecking situation in Europe, peacekeeping missions and operations are described. The peculiarities of the activities of the special monitoring mission of the OSCE in Ukraine are singled out. It is emphasized that field operations are established at the invitation of the respective host countries and their mandates are approved by consensus among participating States.

They support host countries in enhancing their capacity by implementing projects that meet the needs and needs of the host country. It is concluded that the OSCE serves as a forum for political dialogue on a wide range of security issues and a platform for joint action to improve the lives of people and communities. The OSCE contributes to

( ) ДУБОВИК В.Б. - кандидат юридичних наук 
overcoming differences of trust and cooperation, both within and between states. Where there is instability, the OSCE works on conflict prevention, crisis management and postconflict reconstruction.

Through its institutions, expert units and the OSCE network, it addresses a range of issues affecting our common security, including arms control, terrorism, terrorism, terrorism, energy security, human trafficking, democratization, freedom of the media and national minorities. Together with the OSCE, Ukraine responds to the challenges of today and forms a safe dimension for pan-European policy. In addition, the intensification of Ukraine's cooperation with the OSCE is regarded as one of the most important components of the process of European and Euro-Atlantic integration of our country, realization of national interests of our country, ensuring its territorial integrity and inviolability of borders, stability, international recognition, development as a democratic rule of law.

Key words: OSCE, OSCE special monitoring mission, security, Ukraine, international conflict, non-international conflict, peacekeeping activity.

Постановка проблеми. Євроінтеграційна політика України та проголошення західноєвропейського вектора передбачає активізацію діяльності України у рамках міжнародних організацій у безпековій сфері. Особливої уваги заслуговує членство України в Організації з безпеки та співробітництва в Європі (далі - ОБСС) та співпраця з інституціями даної трансатлантичної без пекової структури, що, своєю чергою, сприяє реалізації головних національних інтересів України - утвердження її на світовій політичній арені, як незалежної, суверенної, демократичної, правової держави, забезпечення стабільності розвитку, територіальної цілісності та недоторканності кордонів, зміцнення міжнародного авторитету. Тому пошук ефективних механізмів співпраці України з ОБСЄ у галузі формування системи європейської безпеки і стабільності є надзвичайно актуальною та суспільно значущою проблемою.

Рівень дослідження проблематики. Вказана проблематика досліджувалась у працях таких зарубіжних дослідників, як Ж. Б. Дюрозель, П. Кальвакорессі, Е. Хобсбаум, Дж. Гренвіл. Серед українських науковців рівень впливу ОБСЄ досліджували О. Павлюк, В. Волошин, Б. Гуменюк, Т. Циганкова, Т. Гордєєва, Г. Шелест, Л. Чекаленко тощо. Однак у наукових публікаціях вищезазначених дослідників не приділялось достатньої уваги ролі України (як повноправного члена ОБСЄ) у формуванні не лише європейської але й світової системи безпеки.

Відтак метою статті $є$ дослідження основних етапів та напрямків співробітництва України з ОБСС під час формування сучасної світової системи безпеки.

Виклад дослідження. Усі важливі правові еволюційні процеси, що відбуваються в рамках європейського співтовариства віддзеркалюються на рівні такого впливового суб'єкта як ОБСЄ, Як регіональна структура, ОБСЄ - найширша за своїм складом організація у сфері безпеки в Свропі. Цей інститут став центром ухвалення найважливіших політичних рішень у галузі безпеки й оборони. Якщо порівняти за широтою охоплення сфери дії та території функціонування то ОБСЄ $\epsilon$ безумовним лідером порівняно із НАТО і ЗСС.

Політична значущість ОБСЄ полягає у тому, що це фактично єдина європейська організація у сфері безпеки, яка безпосередньо займається раннім попередженням і вирішенням конфліктів та посткризовою відбудовою, широко застосовуючи методи превентивної дипломатії. Як найбільша з існуючих регіональних організацій безпеки, ОБСЄ сприяє розробленню нової, що грунтується на співробітництві, моделі всеосяжної європейської безпеки. Зокрема, ОБСЄ вирішує широкий спектр питань безпеки: контроль над озброєнням; превентивна дипломатія, запобігання конфліктам, урегулювання криз і постконфліктне відновлення, протидія тероризму, захист прав людини, розгляд питань економічної та екологічної безпеки [1, с. 273].

Організація з безпеки та співробітництва в Європі - єдина трансатлантична безпекова структура, повноправним членом якої є Україна з 30 січня 1992 року, коли перший Президент незалежної України Л. Кравчук підписав Гельсінкський заключний акт. Як повноправний член цієї безпекової організації, Україна відіграє конструктивну об'єднувальну роль у безпековому міжнародному діалозі, що відбувається на платформі ОБСЄ з урахуванням інтересів усіх держав-учасниць; проводить активну зовнішню політику, яка грунтується на дотриманні принципів інорм ОБСЄ щодо непорушності європейських кордонів - основи усієї системи безпеки та стабільності; сприяє зміцненню безпеки в регіоні у політичному, військово-політичному, людському, еко- 
номічному, екологічному та інших вимірах, що, своєю чергою, забезпечує формування безпеки власної держави. Результатом активної співпраці України з ОБСЄ стала ефективна міжнародна миротворча діяльність нашої держави, зміцнення режиму кордонів, результативна міграційна політика; проведення спільних з ОБСЄ заходів протидії нетрадиційним загрозам, таким як зростання міжнародного тероризму, посилення конфліктогенності в окремих регіонах [2, с. 115].

У військовій області ОБСЄ прагне до підвищення відкритості, прозорості та співпраці, і створила найсучасніший в світі режим контролю над озброєннями і заходів зміцнення довіри. Напрямки роботи включають в себе реформування сектора безпеки і безпечного зберігання та утилізації легкого і стрілецької зброї та звичайних боєприпасів [3].

Важливим та результативним напрямом співпраці України з ОБСє є формування нового політичного та безпекового простору у Чорноморському регіоні, налагодження діалогу між провідними державами цього регіону, активізація процесів врегулювання регіональних конфліктів [2, c. 117].

ОБСЄ також протидіє викликам безпеки, що несе транснаціональний характер, таким як насильницький екстремізм і радикалізація, що ведуть до тероризму, кіберзлочинність, великі міграційні потоки, незаконний оборот наркотиків і зброї, торгівля людьми, а також зміна клімату і вплив людини на зміну клімату. Це ті сфери, де державам в силу необхідності потрібно працювати разом. У всіх напрямах своєї діяльності ОБСЄ працює над просуванням гендерної рівності та займається залученням молоді [3].

Представники України в ОБСЄ постійно реагує на висловлені рекомендації викладених на засіданнях Ради міністрів та Постійної ради ОБСЄ та сприяє формуванню безпекового виміру зовнішньої політики. Це проявляється аналогічно і в співпраці нашої держави з Верховним комісаром ОБСС у справах національних меншин (ВКНМ), Бюро з демократичних інститутів і прав людини (БДІПЛ) та Представником ОБСС з питань свободи ЗМІ. Крім того, важливим напрямком спільної діяльності стало ефективне співробітництво з Місією ОБСЄ в Україні, а також із Координатором проектів ОБСС у нашій державі [2, с. 116]. Саме ці проекти зорієнтовані на проблематику властиву українському суспільству. Пріоритетними цілями співпраці України з ОБСЄ у процесі формування системи європейської безпеки та стабільності є: зміцнення потенціалу ОБСЄ як платформи для політичного діалогу та інструменту раннього попередження конфліктів, врегулювання кризових та конфліктних ситуацій; постконфліктне відновлення; пошук моделей мирного врегулювання регіональних конфліктів (Придністровського, Грузинського, Нагірно-Карабахського тощо) та забезпечення посередницької ролі ОБСЄ; посилення потенціалу ОБСЄ у боротьбі з транснаціональними викликами та загрозами європейській та світовій безпеці (боротьба з проявами тероризму, незаконним обігом наркотиків, організованою злочинністю, протидія загрозам, що надходять з кіберпростору); удосконалення польових операцій ОБСЄ, зміцнення аналітичного потенціалу Організації, забезпечення дотримання принципу географічної рівності у кадровій політиці; подальша розбудова та зміцнення в рамках ОБСЄ діалогу з питань енергетичної безпеки [2, с. 118].

Україна активно підтримує пропозиції держав-учасниць ОБСЄ про розширення партнерської співпраці ОБСЄ з іншими світовими безпековими структурами - НАТО, Радою безпеки $\mathrm{OOH}, \mathrm{CC}$, Радою Європи; бере активну участь в обговоренні актуальних питань формування архітектури загальноєвропейської безпеки, виступає за удосконалення інститутів і механізмів ОБСЄ. Таким чином, підтримуючи діяльність ОБСЄ, що тісно працює з іншими міжнародними і регіональними організаціями і співпрацює з країнами-партнерами в Середземномор'ї та Азії. Вона залучає до своєї діяльності громадянське суспільство і збільшує коло інших партнерів, включаючи наукове співтовариство, а також приватний сектор і сектор розвитку.

Крім того, Україна, як повноправний член ОБСЄ, активно виступає з різноманітними пропозиціями та ініціює проекти щодо збереження безпеки та вирішення існуючих конфліктів. Ще на Стамбульському саміті ОБСЄ 1999 р. Україна внесла пропозицію про створення Центру етнічних досліджень під егідою Верховного комісара у справах національних меншин, який має виявляти й розглядати глибинні причини потенційних регіональних конфліктів та визначати шляхи їх подолання. Пізніше українська сторона активно висловлювалась за нерозміщення ядерної зброї на території держав Центральної та Східної Європи, за вироблення механізму надання додаткових гарантій безпеки державам, які цього потребують і не є учасницями структур колективної оборони, серед яких, зокрема, є й Україна [4].

Польові операції створюються на запрошення відповідних приймаючих країн, а їх мандати затверджуються державами-учасниками на основі консенсусу. Вони надають підтримку 
приймають їх країнам в підвищенні потенціалу шляхом реалізації проектів, що відповідають потребам і потребам приймаючої країни.

Деякі місії ОБСЄ працюють над зниженням напруженості - як Спеціальна моніторингова місія на Україні, яка включає в себе понад 700 цивільних спостерігачів. Одним з основних напрямів діяльності ОБСЄ є врегулювання затяжних конфліктів у регіоні в рамках узгоджених форматів. Сюди входять переговори, метою яких є досягнення всеосяжного політичного врегулювання придністровського конфлікту; Мінська група ОБСЄ, яка займається пошуком шляхів мирного врегулювання нагірно-карабахського конфлікту на основі переговорів; а також женевські міжнародні дискусії, початок яким було покладено після конфлікту в Грузії в серпні 2008 року, де ОБСЄ $\epsilon$ співголовою разом з Організацією Об’єднаних Націй та Європейським союзом [3].

Україна $є$ активним учасником миротворчих місій ОБСЄ, зокрема, в Македонії, Косово, Грузії, Таджикистані та Хорватії. Наша держава активно працює в рамках Спільної консультативної групи щодо виконання положень Заключного акта Стамбульського саміту ОБСЄ.

Свідченням активної участі України в обговоренні та вирішенні актуальних проблем міжнародної безпеки і співпраці в європейському регіоні стало надане право Україні головувати в ОБСЄ упродовж 2013 р. Результати головування України в ОБСЄ протягом 2013 року довели спроможність нашої держави ефективно виконувати керівні функції в організації, засвідчили активну участь України у регіональному та міжнародному безпековому діалозі. Упродовж українського головування значна увага приділялась врегулюванню тривалих конфліктів на просторі ОБСЄ. Зокрема, вдалося забезпечити збереження динаміки у процесі придністровського врегулювання, проведено три раунди переговорів 3 придністровського врегулювання у форматі «5+2» [2, c. 119].

Висновки. ОБСЄ є форумом для політичного діалогу з широкого кола питань безпеки i платформою для спільної діяльності щодо поліпшення життя людей і співтовариств. ОБСЄ сприяє подоланню розбіжностей формуванню довіри і співпраці, як між державами, так і всередині них. Там, де є нестабільність, ОБС€ працює над запобіганням конфліктів, регулюванням криз і постконфліктним відновленням За допомогою своїх інститутів, експертних підрозділів і мережі польових операцій ОБСЄ займається низкою запитань, що впливають на нашу загальну безпеку, включаючи контроль над озброєннями, тероризм, належне врядування, енергобезпека , торгівлю людьми, демократизацію, свободу засобів масової інформації та національні меншини.

Спільно з ОБСє Україна реагує на виклики сучасності та формує безпековий вимір загальноєвропейської політики. Крім того, активізація співробітництва України з ОБСЄ розглядається як один із найважливіших компонентів процесу європейської та євроатлантичної інтеграції нашої держави, реалізації національних інтересів нашої країни, забезпечення її територіальної цілісності та недоторканості кордонів, стабільності, міжнародного визнання, розвитку як демократичної правової держави.

\section{Список використаних джерел:}

1. Макар Ю.І. Україна в міжнародних організаціях: навч. посіб. / [Макар Ю.І., Гдичинський Б.П., Макар В.Ю. та ін.]. Чернівці : Прут, 2009. 880 с., с. 273-275.

2. Ільницька У. Україна-ОБСЄ: активізація співробітництва у формуванні Свропейської системи безпеки та стабільності / У. Ільницька // Українська національна ідея: реалії та перспективи розвитку. 2015. Вип. 27. С. 115-121.

3. Офіційний сайт ОБСЕ. URL: https://www.osce.org/ru/whatistheosce/ factsheet?download=true.

4. Інтеграційні проекти України з регіональними та універсальними міжнародними структурами. URL: http:// www.pidruchniki.ws/11570718/ politologiya/integratsiyni_proekti_ukrayini_ regionalnimi_universalnimi_mizhnarodnimi_strukturami/.

5. Фаррух Зейнал оглу Агазаде. Україна в ОБСЄ: двадцять років участі у вирішенні актуальних міжнародних проблем. URL: http://www.histans.com/JournALL/mo/mo_2012_21/13. pdf.

6. Ясірова Ю.Ф. Механізми ОБСЄ із врегулювання конфліктів в новій системі європейської безпеки. URL: http://www.istfak-mgu.at.ua/ publ/procesi_regionalizaciji_ta_globalizaciji_jak dominanta_svitovogo_rozvitku/mekhanizmi_obse_iz_vreguljuvannja_konfliktiv_rol_v_novij_sistemi_evropejskoji_bezpeki/. 